\title{
Mechanical variations induce by foot orthoses on calcaneal fracture
}

\author{
T Breard ${ }^{1,2,3^{*}}, M$ Janin ${ }^{1,2}$ \\ From 4th Congress of the International Foot and Ankle Biomechanics (i-FAB) Community \\ Busan, Korea. 8-11 April 2014
}

This work is meant to quantify the benefits of the foot orthoses $[1,2]$ through the clinical case of a female patient aged 67 who broke her right calcaneum.

To investigate this, we implemented three experiments commonly used during podiatric examinations to assess walking parameters: the passive antepulsion test, the stabilo-baro-podometrie analysis [3,4] and the Latero-Medial Index, measures taken immediately (T0) and after 16 days (T16) wearing plantar orthotics. (figure 1) Foot orthoses, deduced after clinical examination and quantitative analysis of walking, are molded, wisch are supplemented by the addition of specific low stimulations. The results clearly show the benefits on stability. The foot orthoses allows the patient to recover the normal use of the ankle thanks to the positive effects on support and movement of a fractured foot [5]. Therefore, the foot orthoses tends to improve the balance of the fractured foot. Moreover, these positive effects are persistent throughout the time.

In a latter phase, the adjustments carried out on the foot orthoses that modify the foot simulation $[3,4]$,

\section{T0, Force Cuves without foot orthose. left / right}
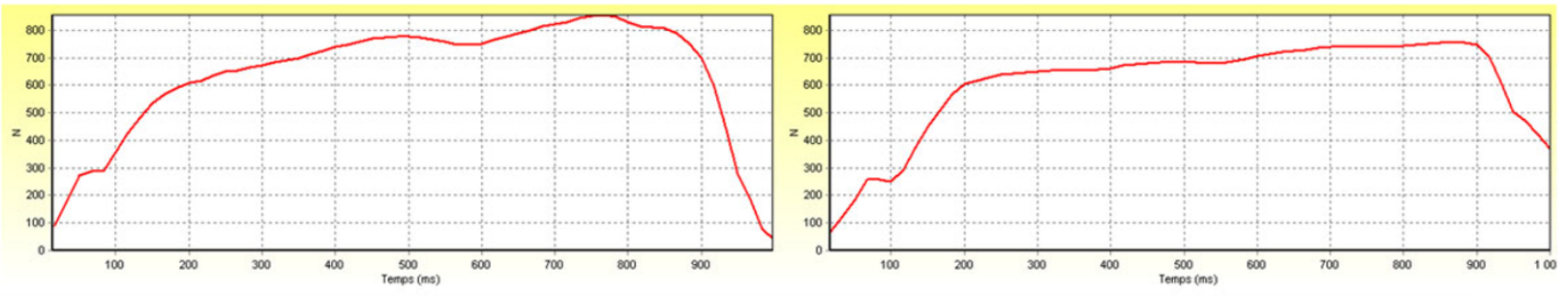

T16, Force Cuves without foot orthoses. left / right
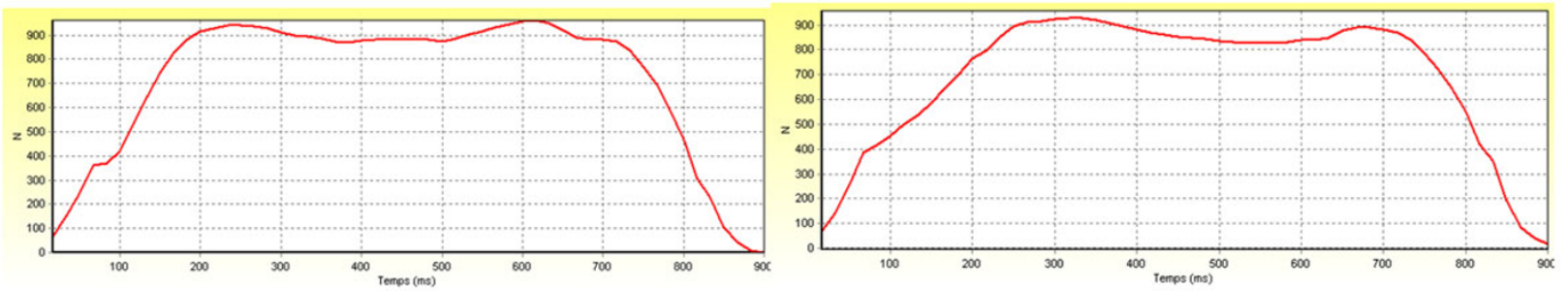

Figure 1 T0, Force Cuves without foot orthose. Left/Right and T16, Force Cuves without foot orthoses. Left/right

${ }^{1}$ Applied Podiatry College, 7 Treguel, 86000 Poitiers, France

Full list of author information is available at the end of the article

(c) 2014 Breard and Janin; licensee BioMed Central Ltd. This is an Open Access article distributed under the terms of the Creative Commons Attribution License (http://creativecommons.org/licenses/by/4.0), which permits unrestricted use, distribution, and reproduction in any medium, provided the original work is properly cited. The Creative Commons Public Domain Dedication waiver (http://creativecommons.org/publicdomain/zero/1.0/) applies to the data made available in this article, unless otherwise stated. 
result in the improvement of the assessed parameters (static and dynamic). These variations tend to prove the benefits of the foot orthoses and justify the podiatric approach developed on this clinical case.

\section{Authors' details}

${ }^{1}$ Applied Podiatry College, 7 Treguel, 86000 Poitiers, France. ${ }^{2}$ Podiatrist, PhD, Clinic, 7 Trequel, 86000 Poitiers, France. ${ }^{3}$ Maison médical de Roaillan, 33210 Roaillan, France.

Published: 8 April 2014

\section{References}

1. Murley GS, Landorf KB, Menz HB: Do foot orthoses change lower limb muscle activity in flat-arched feet towards a pattern observed in normal-arched feet? Clin Biomech 2010, 25:728-736.

2. Murley GS, Landorf KB, Menz HB, Bird AR: Effect of foot posture, foot orthoses and footwear on lower limb muscle activity during walking and running: a systematic review. Gait Posture 2009, 29:172-87.

3. McPoil TG, Cornwall MW: Use of plantar contact area to predict medial longitudinal arch height during walking. JAMPA 2006, 96:489-494.

4. Wong L, Hunt A, Burns J, Crosbie J: Effect of foot morphology on centerof-pressure excursion during barefoot walking. JAPMA 2008, 98:112-127.

5. Gillespie WJ, Gillespie LD, Paker MJ: Hip protectors for preventing hip fractures in older people. Cochrane Database Syst. Rev 2010, 6(10): CD001255.

6. Janin M, Dupui P: The effects of unilateral medial arch support stimulation on plantar pressure and center of pressure adjustment in young gymnasts. Neuroscience Letters 2009, 461:245-248.

7. Janin $M$, Toussaint $L$ : Change in center of pressure with stimulations via anterior orthotic devices. Gait Posture 2005, 21:1.579.

doi:10.1186/1757-1146-7-S1-A9

Cite this article as: Breard and Janin: Mechanical variations induce by foot orthoses on calcaneal fracture. Journal of Foot and Ankle Research 2014 7(Suppl 1):A9.

\section{Submit your next manuscript to BioMed Central and take full advantage of:}

- Convenient online submission

- Thorough peer review

- No space constraints or color figure charges

- Immediate publication on acceptance

- Inclusion in PubMed, CAS, Scopus and Google Scholar

- Research which is freely available for redistribution

Submit your manuscript at www.biomedcentral.com/submit
C Biomed Central 